УДК 338.3

\title{
МАРКЕТИНГОВИЙ МЕНЕДЖМЕНТ НА ФОНІ ПІДПРИЄМНИЦЬКОЇ ДІЯЛЬНОСТІ В УКРАЇНІ
}

\section{MARKETING MANAGEMENT ON THE BACKGROUND OF ENTREPRENEURIAL ACTIVITY IN UKRAINE}

\author{
Поліщук Сергій Володимирович \\ кандидат економічних наук, доцент, \\ Національний технічний університет України \\ «Київський політехнічний інститут імені Ігоря Сікорського» \\ ORCID: https://orcid.org/0000-0003-0648-5849 \\ Вітченко Євгеній Валерійович \\ студент, \\ Національний технічний університет України \\ «Київський політехнічний інститут імені Ігоря Сікорського» \\ ORCID: https://orcid.org/0000-0002-8349-627X
}

\author{
Polyschuk Sergii, Vitchenko Evgeniy \\ National Technical University of Ukraine \\ «lgor Sikorsky Kyiv Polytechnic Institute»
}

\begin{abstract}
Стаття присвячена актуальним питанням здійснення маркетингового менеджменту на фроні підприємницької діяльності в Україні. Маркетинговий менеджмент - це процес планування і реалізації концепцій ціноутворення, просування й розподілу ідей, товарів і послуг, спрямований на здійснення обмінів, котрі задовольняють як індивідуальні, так і організаційні цілі. Маркетингове управління ґрунтується на фрункціях управління, включаючи ідеї, товари, послуги як основні категорії, його головне завдання полягає в досягненні відчуття задоволеності всіма сторонами обміну. Концепцію стратегічного маркетингу засновано на ефективному розподілі обмежених ресурсів у процесі трансорормації маркетингової інфрормації в маркетингові дії.

Ключові слова: маркетинг, менеджмент, маркетинговий менеджмент, підприємницька діяльність, підприємницька діяльність в Україні.
\end{abstract}

Статья посвящена актуальным вопросам осуществления маркетингового менеджмента на фроне предпринимательской деятельности в Украине. Маркетинговый менеджмент - это процесс планирования и реализации концепций ценообразования, продвижения и распределения идей, товаров и услуг, направленный на осуществления обменов, которые удовлетворяют как индивидуальные, так и организационные цели. Маркетинговое управление основывается на функциях управления, включая идеи, товары, услуги как основные категории, его главное задание заключается в достижении ощущения удовлетворенности всеми сторонами обмена. Концепция стратегического маркетинга основана на эфорективном распределении ограниченных ресурсов в процессе трансформации маркетинговой инорормации в маркетинговые действия.

Ключевые слова: маркетинг, менеджмент, маркетинговый менеджмент, предпринимательская деятельность, предпринимательская деятельность в Украине.

The article is devoted to topical questions of realization of marketing management on a background entrepreneurial activity in Ukraine. Marketing management is the process of planning and realization of conceptions of pricing, advancement and distribution of ideas, commodities and services, sent to realizations of exchanges, that satisfy both individual and organizational aims. Marketing management is based on functions of management, including ideas, commodities, services as basic categories, its main task lies in achievement of feeling of satisfaction of all parties of exchange. The conception of strategic marketing is based on effective allocation of limited resources in the process of transformation of marketing information into marketing actions. Development and bringing a new commodity or a service to the market are conditioned by such factors: by necessity to protect a company from the consequences of inevitable process of aging of commodities, caused by a competition or obsolescence. Decline of profitability of commodities that produce, or services that give, it is possible to compensate in a long-term plan only 
due to introduction of a new commodity (service) that would have demand for a consumer. Manufacturing of a new product or a service to the assortment is needed for defence of the facilities already inlaid in a company; by necessity to extend a production more rapid rates, than it maybe at the narrow range of goods that produce, distribute a commercial risk on more wide spectrum of commodities and services, to diminish influence of competition on the separate sphere of activity of company; by necessity to provide quicker and gradual increase of the general profitability of company, expressed by attitude of profit toward the inlaid capital, by maintenance and increase of competitiveness, more rational use. Planning of assortment entails coordination of a whole number of associate types of activity: scientifically technical researches and development of market, organization of motion of a commodity, sales and advertisement promotion researches. Maximal efficiency is arrived at not so due to optimization of every element separately, as by the sum of component parts.

Keywords: marketing, management, marketing management, entrepreneurial activity, entrepreneurial activity in Ukraine.

Постановка проблеми. Для успішного управління підприємницькою діяльністю існує потреба в створенні доцільної економічної маркетингової стратегії, а також плану управління підприємством. Наразі підприємницька діяльність в Україні потребує внесення деяких змін у структуру та методи управління.

По-перше, все помітнішою стає досить низька ефрективність стратегій управління підприємством. Як результат - низькі показники збуту товарів та послуг. По-друге, підприємці не завжди підбирають вдалий та доцільний метод організації маркетингової діяльності.

Саме через ці питання дана тема $\epsilon$ актуальною у розрізі ведення економіки України та підтримки малого та середнього бізнесу в нашій країні.

Аналіз останніх досліджень та публікацій. Існує досить багато цікавих робіт вчених та економістів на тему маркетингу, методів збуту продукції на підприємстві. Серед них можна виділити праці Т.Б. Решетілової [1], О.В. Ольшанського [2], О.П. Красняка [3], О.Л. Анусррієвої [4].

Виділення невирішених раніше частин загальної проблеми. Виходячи 3 того, що підприємницька діяльність поступово розвивається, спираючись на вищезгадані праці, у даній статті будуть виявлені питання, що наразі $€$ невирішеними, а також будуть запропоновані рішення даних частин проблеми.

Формулювання цілей статті. Метою даної статті $\epsilon$ вирішення проблем сучасного ведення маркетингового менеджменту на фроні підприємницької діяльності в Україні, а також пропозиції покращення створення стратегій щодо управління підприємством та збуту продукції.

Виклад основного матеріалу. Маркетинговий менеджмент - це процес планування і реалізації стратегій просування товарів та послуг, які виробляють та надають підприємства.

Маркетинговий менеджмент ґрунтується на фрункціях управління, а також задоволенні потреб та попиту споживача на товари та послуги. Також, дуже важливу роль в успішному керуванні виробництва грає одна з найрозвиненіших фрорм міжнародної торгівлі в бізнесі та ведення підприємницької діяльності - експорт. Він являє собою вивезення та подальший збут продуктів (у тому числі інтелектуальної діяльності), послуг за кордон.

Експорт має деякі ризики, особливо в плані логістики. Також, експортом можна назвати стратегію підприємства, адже саме за рахунок продажу товарів за кордон підприємство має змогу вийти на зарубіжний ринок та знайти нових споживачів, які $€$ дуже важливим аспектом та ланкою в успішній діяльності малого, середнього та великого бізнесу.

Наразі в Україні $є$ проблема старіння технологій виробництва великої кількості товарів, знос технологічного устаткування. Для вирішення даної проблеми ми рекомендуємо звертатись до досвіду зарубіжних бізнес-колег різних направлень. Це допоможе запозичити, а у довгостроковій перспективі - винайти свої методи введення інновацій у створення нової продукції. Інноваційні рішення $€$ рушієм розвитку підприємства та бізнесу загалом.

Введення нових товарів в асортимент продукції не тільки допоможе набути нових клієнтів та споживачів, але й сприяє реінвестуванню прибутку у виробництво товарів за сучасними технологіями, підвищення ефективності використання робочих та технологічних ресурсів і прискорення виробництва, не нехтуючи контролем якості виробленої продукції та послуг.

Необхідно відмітити, що існують деякі чинники, які зазвичай впливають на поведінку споживачів на ринку товарів та послуг. Серед них: уміння переконувати придбати той чи інший товар або послугу, рівень платоспроможності покупця, тип особистості споживача.

При плануванні асортименту продукції компанії виникає потреба проведення додаткових 
видів діяльності, а саме: дослідження ринку, на якому $є$ подібні види товарів або послуг; аналіз конкурентів, їх технологій виробництва та цільової аудиторії споживачів; науково-технічні дослідження виробництва такого виду товарів та надання послуг; безперервне стимулювання збуту власної продукції; створення необхідних маркетингових стратегій задля успішного виходу нового товару на ринок; пошук способів модернізації минулих товарів, які мали попит на споживчому ринку та репутацію якісного, а головне - корисного товару, яких повністю задовольняє потребу клієнтів підприємства. Слід зазначити, що існує небагато підприємств та бізнес-одиниць, компаній, які використовують та слідують усім вищезгаданим пунктам успішного збуту продукту.

При випуску нового товару на ринок в Україні, підприємці стикаються 3 деякими ризиками, серед них: зміна споживчих переваг, дії конкурентів в даному сегменті ринку (даний продукт може не мати переваг над аналогічним продуктом конкурентів), науково-технічний прогрес, за рахунок якого у підприємства можуть виникнути проблеми з використанням новітніх технологій та розробок, а головне підходів до створення модернового продукту.

Дуже важливим при випуску продукції для підприємства $€$ те, що виробник товару має провести аналіз галузі, в якій відбувається виробництво. Необхідно визначити конкурентні сили та переваги, а також конкурентну позицію даного підприємства. Задля цього компанія може створити альтернативні конкурентні стратегії свого розвитку, щоб проводити успішну діяльність. Наступним етапом $\epsilon$ доцільний вибір однієї з цих стратегій.

Виробнику необхідно оцінити суперництво між конкурентами, які виготовляють подібну продукцію, а також дати оцінку своїм економічним можливостям, адже сам вони надають змогу підприємству реінвестовувати прибуток у розвиток технологій виробництва, закупівлю устаткування, створення серій продукту для різних сегментів ринку та покупців з різною платоспроможністю. Дані аспекти направлені на збільшення доходу та популяризацію і вихід компанії на новий рівень як з точки зору якості, так і у конкурентному аспекті.

Українські бізнес-підприємці також мають деякі труднощі із набуттям достатньо стійкого становища у своєму сегменті ринку. Для вирішенні цього питання потрібно звернути увагу на забезпечення низької ціни за високої якості продукції. Також, з точки зору сервісу, в рамках гарантії, слід забезпечити гідну репутацію у даному аспекті, адже саме післяпродажне обслуговування товарів $€$ чинником залучення нової клієнтури.

3 точки зору організаційних можливостей, українське підприємство має забезпечити себе необхідними та досконалими інфрормаційними системами. Туди також входить і здійснення електронної комерції, як складова організаційних можливостей підприємства.

Досить часто у виробничих компаніях України можна спостерігати не досить високу квалісрікацію маркетингового відділу. Їхня задача залучити та потенційного покупця у придбанні товару, запевнити його в тому, що саме цей вид продукції є для нього необхідним. Тому це $\epsilon$ дуже важливим моментом у розрізі виробництва та фрінального збуту продукції.

В українській підприємницько-виробничій діяльності також існує проблема зворотнього зв'язку, який кожна компанія повинна отримувати від свого споживача, адже це також $є$ частиною вдалого методу організації маркетингового менеджменту на підприємстві. Даний етап $є$ настільки ж важливим, наскільки й аналіз потреб споживача, які можуть іноді не збігатися з видами виробленої продукції. Саме для 3'ясування потреб клієнта використовується зворотній зв'язок. Він може бути у вигляді он-лайн опитування споживачів, наприклад, на сайті бізнес-компанії. Саме даний пункт допоможе з'ясувати, чи був випуск нової продукції сприятливим для розвитку підприємства та підвищенні продуктивності його діяльності. Цей етап є заключним у створенні та проведенні доцільного маркетингового менеджменту підприємств в Україні.

Висновки. Проведене дослідження маркетингової діяльності в Україні показало, що існують проблеми доволі низької ефективності стратегій управління підприємством або бізнес-компанією, а також проблема правильного підбору вдалого та доцільного методу організації маркетингової діяльності та управління підприємством. Маркетинговий менеджмент у підприємницькій діяльності ставить перед собою ціль відповідності потребам споживача, створення вірної стратегії просування товарів та послуг, а також задля успішного фрункціонування підприємства необхідна координація заходів бізнес-компанії. Рішеннями вищезгаданих проблем та досягнення цілей у сорері управління підприємством є: дослідження аналогічної галузі конкурентів; обмін досвідом з іноземними бізнес-одиницями, які займаються виробництвом та наданням подібних послуг; винайдення нових 
методів модернізації старих видів продукції та створення нових та якісних продуктів; дослідження споживчого сегменту ринку та створення можливості надання зворотнього зв'язку від споживачів. Дані рішення мають поліпшити загальне становище підприємств в Україні та їх виходу на абсолютно новий, конкурентний рівень.

\section{СПИСОК ВИКОРИСТАНИХ ДЖЕРЕЛ:}

1. Решетілова Т.Б., Довгань C.M. Маркетингові дослідження. Дніпропетровськ : НГУ. 2015. URL: http://nmu.org.ua

2. Ольшанський О.В. Аналіз методів удосконалення бізнес-процесів підприємств торгівлі. Держава та регіони. Серія : економіка та підприємництво. 2019. № 2. URL: http://nbuv.gov.ua/UJRN/drep_20-19_2_20

3. Красняк О.П., Амонс С.Е. Маркетингові дослідження ринку і його структурних елементів: теоретичний аспект. Електронний журнал «Ефективна економіка». 2020. № 5. doi: 10.32702/2307-2105-2020.5.106. URL: http://www.economy.nayka.com.ua/?op=1\&z=7926/

4. Ануфрієва О.Л., Пальчевська Т.Г., Лагоцька Г.М. Підприємницька діяльність : Навчальний посібник. Івано-Франківськ : Лілея-НВ, 2014. С. 138-156. URL: http://umo.edu.ua/images/content/depozitar/navichki_pracevlasht/ pidpryemn_diyaln.pdf

\section{REFERENCES:}

1. Reshetilova T.B., Dovgan S.M. (2015) Marketyngovi doslidzhennya [Marketing researches]. Dnipropetrovsk: NGU. Available at: http://nmu.org.ua (in Ukrainian)

2. Olshanskyj O.V. (2019) Analiz metodiv udoskonalennia biznes-protsesiv pidpryiemstv torhivli Information systems and technologies in the management of the enterprise activity [Analysis of methods for improving the business processes of trade enterprises]. Derzhava ta rehiony, no. 2. Available at: http://nbuv.gov.ua/UJRN/ drep_2019_2_20 (in Ukrainian)

3. Krasnyak O.P., Amons S.E. (2020) Marketyngovi doslidzhennya rynku i joho strukturnykh elementiv: teoretychnyj aspect [Marketing researches of market and its structural elements: theoretical aspect]. Efektyvna ekonomika [Online], no. 5. doi: 10.32702/2307-2105-2020.5.106. Available at: http://www.economy.nayka.com.ua/ ?op=1\&z=7926/ (in Ukrainian)

4. Anufrieva O.L., Palchevska T.H., Lahotska H.M. (2014) Pidpryemnytska diyalnist' [Entrepreneurial activity]. [Tutorial]. Ivano-Frankivsk: Lileya-NV. Available at: http://umo.edu.ua/images/content/depozitar/na-vichki_ pracevlasht/pidpryemn_diyaln.pdf (in Ukrainian) 